\title{
105. めまいと超音波血流計による椎骨動脈血流速度
}

\section{○佐野光仁・松永 亨・久保 武・稲留欣一（関西労災病院）}

\section{1) 目的}

めまいを訴える患者に最近，いわゆる椎骨脳底動脈循 環不全症なる診断名がしばしば用いられる．この椎骨膇 底動脈循環不全症の診断に対して, Doppler 法による超 音波血流測定法がどのような意義を有するか検討した．

\section{2) 原理と方法}

血管に超音波が投射されると動いている赤血球により 反射波 Doppler は効果で周波数が変化する，投射なら びに反射超音波の周波数の差は血流速度に比例する可聴 の腍り音を生じる。この唸り音の記録方式には周波数弁 別方式, 周波数計数方式，スペクトログラム方式の方法 があるが，我々の記録法怯心電図の第誘遒の QRS の 立ち上がりを Trigger に利用し，周波数計数方式によ り得られた流速波形を日本光電製 ATAC-201にて15回 平均加算を行い, X-Y レコーダーに記録した.

\section{3) 血流速度}

前述の方式により椎骨動脈血流速度及び総頸動脈血流 速度を記録すると健康成人（29名の平均）では，椎骨動 脈の収縮期の最大血流速度は右側では $13.6 \pm 5.9 \mathrm{~cm} / \mathrm{sec}$, 左側では $13.8 \pm 6.0 \mathrm{~cm} / \mathrm{sec}$, 拡張期の最大血流速度は右 側では $7.1 \pm 3.1 \mathrm{~cm} / \mathrm{sec}$, 左側 $7.2 \pm 3.1 \mathrm{~cm} / \mathrm{sec}$, 収縮期の 血流速度の左右差は $2.3 \pm 2.7 \mathrm{~cm} / \mathrm{sec}$, 総頸動脈最大血流 速度は収縮期では右側 $60.9 \pm 15.5 \mathrm{~cm} / \mathrm{sec}$, 左側 $58.9 \pm$ $12.8 \mathrm{~cm} / \mathrm{sec}$, 拡張期では右側 $14.4 \pm 5.9 \mathrm{~cm} / \mathrm{sec}$, 左側 13.1 $\pm 4.3 \mathrm{~cm} / \mathrm{sec}$ ，收縮期の血流速度の左右差 $9.2 \pm 14.4 \mathrm{~cm} /$ sec であり，総頚動脈最大血流速度は収縮期では椎骨動 脈最大血流速度の約 4 倍, 拡張期では約 2 倍である事が 判つた. 又めまい症例38名について同様に血流速度を計 算すると, 総頸動脈の血流速度の平均值は収縮期で右側 $59.4 \pm 14.5 \mathrm{~cm} / \mathrm{sec}$, 左側 $59.0 \pm 13.3 \mathrm{~cm} / \mathrm{sec}$ ，拡張期で右 側 $17.6 \pm 7.4 \mathrm{~cm} / \mathrm{sec}$, 左側 $16.8 \pm 8.4 \mathrm{~cm} / \mathrm{sec}$, 椎骨動脈 のそれは収縮期において右側 $15.0 \pm 7.7 \mathrm{~cm} / \mathrm{sec}$, 左側 13.8 $\pm 8.3 \mathrm{~cm} / \mathrm{sec}$, 拡張期に括いては右侧 $7.2 \pm 4.4 \mathrm{~cm} / \mathrm{sec}$, 左 側 $6.8 \pm 4.6 \mathrm{~cm} / \mathrm{sec}$ であり健康成人のそれと比べて著し い差違は認められなかつた。

\section{3）血流速度の低下}

便宜上，血流速度が標準偏差10以下を低下とする時。 收縮時の椎骨動脈最大血流速度の低下は健康成人群では $17 \%$ ，めまい群では 32\%，拡張期のそれは 14\%,34\%と明 らかにめまい群に椎骨動脈血流速度が低いことがわかつ た. 総頸動脈の低下は収縮期において 正常群では 26\%， めまい群では $17 \%$ ，拡張期では $16 \%, 17 \%$ と著しい差異は 認められなかつた。従つて概して総頸動脈の血流異常と めまい孫ないと関係なる。

\section{4) 血流速度の左右差}

椎骨動脈血流速度の左右差を標準偏差の 2 倍以上を病 的左右差とする時，健康成人群では収縮期及び㹡張期の 左右差は 10\%，3\%，めまい群では $42 \% ， 25 \%$ で明らか に, 正常群とめまい群には有意の差がある事が判明し た.しかしながら総頙動脈血流速度においてはめまい群 及び健康成人群の間には血流速度の左右差に有意の差住 認めなかつた。

\section{5）年令と血流速度}

めまい群及び正常群において年令と血流速度の相関関 你を検討したが特に相関を認めなかつた，5）コレステ ロール值と血流速度, 正常群においてはコレステロール の高いものは血流速度の低下する傾向を認めた，一方め まい群においてはそのような傾向を認めなかつた、旬 末梢性, 中枢性障害と血流速度, 平衡機能検查及び神経 学的検查により明確に中枢障害と判明したもの6 例, 末 梢障害と判明したもの14例について椎骨動脈血流速度 総頸動脈血流速度の左右差及び血流速度の減少について 検討したが，何ら特長的な所見は認めなかつた. 6) ま と め

我々が現在行つている測定法による健康成人をめまい 患者の総頸動脈, 椎骨動脈血流動態について述べたが, めまい群では明らかに左右の椎骨動脈血流速度の左右 差, 血流速度の低下を示すものが多い事が判つた. しか しこれをむつて椎骨这底動脈循環不全症と診断するには 向後検討を必要とする. 